\title{
Integration, cultural preservation and transnationalism through state supported immigrant organizations: a study of Sweden's national ethnic associations
}

\author{
Olle Frödin ${ }^{1 *}$ (D, Axel Fredholm ${ }^{1}$ and Johan Sandberg ${ }^{2}$
}

\footnotetext{
* Correspondence: olle.frodin@soc. lu.se

'Department of Sociology, Lund University, Box 114, SE-221 00 Lund, Sweden

Full list of author information is available at the end of the article
}

\begin{abstract}
This paper explores the activities of Swedish state supported ethnic associations (most of which are immigrant organizations), thus shedding empirical light on how immigrants organize with the help of state support, both nationally and transnationally, in a welfare state context. The paper is based on a study of annual reports of 52 state supported national associations, representing more than a thousand (1046) local immigrant organizations, as well as 17 interviews with representatives of the said organizations. The findings indicate that the welfare state did not crowd out civil societal integration-promoting initiatives, but the state supported immigrant organizations came to occupy a niche in which they primarily offered complementary services with the aim of helping members to navigate the public welfare system. Neither did state support directly shape the content and direction of the political activities of the said organizations. However, the state support seems to have generated welfare channeling effects, in that more immigrant organizations came into existence than would have been the case in the absence of grants. The paper comes down in favor of the thesis that state support in some circumstances can promote political incorporation through immigrant organizations (with a few caveats). Finally, the paper proposes a hypothetical mechanism, homeland-oriented integration, for political incorporation through immigrant organization.
\end{abstract}

Keywords: Immigration, Integration, Immigrant organizations, Transnationalism

\section{Introduction}

The study of immigrant organizations has undergone a revival recently, resulting in a growing wealth of international research on the impact of migrants' organizational efforts in both receiving and origin countries. Recent research on immigrant organizations has focused on the role of immigrant organizations in facilitating processes of integration, particularly labor market integration, in receiving countries. At the same time, migration researchers have increasingly focused on organized transnational activities, such as attempts on the part of immigrant organizations to promote development in the countries of origin. This was the shared focus of a relatively recent comparative

(c) The Author(s). 2021 Open Access This article is licensed under a Creative Commons Attribution 4.0 International License, which permits use, sharing, adaptation, distribution and reproduction in any medium or format, as long as you give appropriate credit to the original author(s) and the source, provide a link to the Creative Commons licence, and indicate if changes were made. The images or other third party material in this article are included in the article's Creative Commons licence, unless indicated otherwise in a credit line to the material. If material is not included in the article's Creative Commons licence and your intended use is not permitted by statutory regulation or exceeds the permitted use, you will need to obtain permission directly from the copyright holder. To view a copy of this licence, visit http://creativecommons.org/licenses/by/4.0/. 
research project focusing on transnational migrant organizations, the Comparative Immigrant Organizations Project (CIOP) which included case studies carried out in some ten countries in Asia, Europe, North America, and Latin America (Portes \& Fernández-Kelly, 2015). The CIOP project found that transnational activities were prevalent among immigrant organizations on both sides of the Atlantic, and that receiving- and origin-country oriented activities typically co-exist. However, the European cases differed markedly from the US in that the state had a much more prominent role in Europe. While the US has no history of state support to immigrant organisations, several European states do. For instance, immigrant organizations participate in French development assistance through co-development, with one of the aims being to decrease out-migration pressures (Lacroix \& Dumont, 2015). Similarly, the Spanish government requires immigrant organizations to promote development in the countries of origin as a condition for funding (Cebolla-Boado \& López-Sala, 2015).

To our knowledge, no research in this vein has been conducted in a Scandinavian country context to date. In addition to having universal welfare models guaranteeing extensive welfare services and support to their citizens, the Scandinavian countries have a shared tradition of voluntary civil society organization, a people's movement tradition, into which immigrant organizations are incorporated through a system of state grants. The impact of state support on immigrant organizations has been debated since long. Some scholars, such as Bloemraad (2005) has argued that state intervention can promote immigrants' ability to sustain organizations that function as vehicles of political incorporation. At the same time, 'neo-Tocquevillians' have argued that state support tends to erode the vitality of ethnic organizations. On a more general level, welfare systems have been taken to crowd out immigrant organizations since many member needs will be met by welfare programs (Hein, 1997). In light of more recent research on transnational activities of immigrant organizations, the impact of state support is equally debated. On the one hand, state support strengthens immigrant organizations by providing them with more resources. On the other hand, state support may generate patron-client relations as the priorities of immigrant organizations risk being subordinated to the priorities of state agencies, as Portes (2016, p. 18) points out.

In light of these scholarly debates, this paper surveys the activities of state supported ethnic and immigrant national associations in Sweden. More specifically, the paper is based on an investigation of the activities accounted for in the annual reports of fiftytwo (52) national umbrella associations (riksförbund), representing more than a thousand (1046) local immigrant organizations, as well as seventeen (17) interviews with representatives of the said national associations. The grantee organizations are officially called ethnic organizations, since the Swedish grant regulations make no formal distinction between immigrant and ethnic organizations. However, to qualify for Statefunding at least $51 \%$ of members must have a foreign background (utländsk bakgrund (MUCF, 2018). In this paper, the surveyed associations will therefore henceforth be called immigrant organizations.

This paper investigates the types of activities that immigrant organizations arrange in a welfare state context. Moreover, the paper explores the extent to which, and how, Swedish immigrant organizations relate to their countries of origin, in terms of both political stances and transnational activities more generally. In so doing, the study sheds empirical light on the question of how state support may influence immigrant 
and ethnic organizations. More generally, the study explores what kinds of activities immigrant organizations arrange in a welfare regime, where residents are guaranteed basic public services as a citizen right. By exploring the activities of state supported immigrant organizations within relatively extensive welfare systems, the study provides unique empirical findings on the incorporation of immigrants into Nordic welfare societies.

The paper begins with a conceptual and theoretical overview outlining drivers and contextual factors that shape when and how immigrants organize nationally and transnationally, before it describes the Swedish system of state support to immigrant organizations. Thereafter, the paper accounts for the research methods employed. This is followed by an overview of the surveyed organizational population and an analysis of the organizational activities. The paper ends with a summary and a concluding analysis of the findings.

\section{Why immigrant organizations?}

Setting the stage for this study involves considering why immigrant organizations are established in the first place. In a theoretical review, Babis (2016) suggests a range of economic, cultural, social, and political motives leading to the establishment of immigrant organizations. Most fundamentally, due to various barriers such as language confusion and discrimination, it may be difficult for immigrants to participate or feel at home in preexisting civil society organizations in the receiving country. Hence, immigrant organizations emerge as a response to the special needs of various immigrant groups. For instance, immigrant organizations may serve as platforms for the preservation of language and various aspects of cultures and collective memories, and may also represent the members and their community in various ways. Moreover, the establishment of immigrant organizations may be driven by economic motives, such as a need of self-help or rotating savings and credit associations (Babis, 2016).

In a classical paper, Breton (1964) argues that ethnic communities strive to achieve institutional completeness, that is, an ability to provide as broad a range of services such as education and medical care, as possible for members such that the community does not have to rely on services provided by receiving country institutions. As noted, migrants may also organize for the benefit of both sending and receiving countries. In migration research, the meso-level of migrant organizations has been somewhat neglected. Recently, scholarly interest in the role of immigrant organizations for labor market integration and political incorporation in receiving countries in Europe and North America has grown (Morales \& Ramiro, 2011; Portes et al., 2008; Vermeulen, 2006). At the same time, there is an increased focus on the roles of immigrant organizations for development in sending countries, along with a more general interest in various organized transnational activities (Portes \& FernándezKelly, 2015; Pries \& Sezgin, 2012). The term transnationalism has been used to describe a wide range of different activities, ranging from practices signaling an identity and belonging to various cross-border activities, as Waldinger (2013) notes. As the term transnationalism indicates, migrants typically maintain links to the country of origin, links that were often overlooked by researchers primarily preoccupied with the integration of immigrants into the receiving country. When it comes to immigrant organizations, the term can be defined as organized efforts and activities with a possible bearing on both countries of origin and receiving countries, as well as other countries related to the immigrant group in question. 
Immigrants and immigrant organizations may engage in a wide range of types of transnational activities. For instance, immigrant organizations may engage in various forms of homeland politics, including engagement in electoral politics or the provision of support to various anti-state movements such as separatists or nationalist organizations. Immigrant organizations may act as lobbies that advocate for or against their origin states. In cases of migrant philanthropy, immigrants engage in the countries of origin in a less politically charged manner, such as by sending supplies or monetary aid to humanitarian causes (Waldinger, 2013). Immigrants may also form professional and development-oriented hometown associations that are engaged in the country of origin while attempting to avoid being explicitly political, for instance, by sponsoring welfare institutions or by providing funds for construction projects or disaster relief. In some cases, immigrant organizations collaborate with governments in the countries of origin to carry out development projects, as in the case of Mexico's Tres-Por-Uno program (Faist, 2008).

\section{Resource mobilization and state influence over organizational fields}

Even in the presence of a legal-institutional basis that enables immigrants to organize in the receiving society, all organizations are typically not equally able to undertake collective action. According to resource mobilization theory, collective, organized actions depend on the ability of a group to accumulate the resources required to create formal organizations (Hein, 1997). There are constraints on collective action, such as limitations in terms of economic, human and social capital, as well as differences with regard to wider opportunity structures, and organizational fields, that collectivities and organizations face. As defined by DiMaggio and Powell, an organizational field denotes "sets of organizations that, in the aggregate, constitute a recognized area of institutional life; key suppliers, resource and product consumers, regulatory agencies, and other organizations that produce similar services or products" (1983, p. 148). In the case of immigrant organizations, it is important to note that the fields in question are typically transnational. The term transnational field refers here to the notion that migrants may be embedded in transnational networks where they occupy different social positions of power across several locations (Bloch \& Hirsch, 2018; Koinova, 2018). Immigrant organizations can be involved in wider transnational fields where they influence and are influenced by other public and private organizations, both in the countries of origin and in receiving societies (Collyer \& King, 2015). Within and between fields, immigrant organizations may also be part of various governance networks. A governance network can be defined as interlinkages among interdependent actors who contribute to some form of governance through negotiation and cooperation (Torfing, 2012). Governance denotes relational processes whereby actors and organizations negotiate, reconcile and coordinate goals while retaining their autonomy (Frödin, 2012; Van Kersbergen \& Van Waarden, 2004). For instance, immigrant organizations in receiving countries may be requested to perform tasks for the sending state, in exchange for support. A wider transnational governance network can overlap, complement or conflict with the principles that govern a specific national or local social field, as Torfing (2012) points out, meaning that immigrant organizations may face contradictory and sometimes conflicting pressures in the different fields and networks in which they are part. For instance, sending and receiving states that support one and the same immigrant organization may have conflicting norms and goals. 
So called welfare channeling theory takes as its starting point the fact that government policies may influence the organizational landscape of immigrant communities and consequently, the organizational representation of ethnicity as Hein (1997) argues. For instance, states may sponsor non-profit organizations, including immigrant organizations, such that their existence depends on state support. Alternatively, states may support moderate organizations over radical ones to promote professionalization over protest. In this way, states can generate channeling effects on non-profit organizations and social movements (Hein, 1997). State channeling of resources may also occur transnationally, as in cases of co-development, that is, formal international development collaboration between sending and/or receiving government agencies and immigrant organizations (Nijenhuis \& Broekhuis, 2010). Various forms of state channeling may thus contribute to shaping even the character of transnational activities.

Normatively, the political effects and implications of state channeling are debated, as noted above. On the one hand, Bloemraad $(2005,2006)$ has argued that immigrant organizations can function as vehicles of political incorporation, in that they provide people with political-administrative skills and thus enable immigrants to mobilize for collective participation in the receiving country's political institutions and administrative bureaucracies. By sponsoring immigrant organizations, governments thus promote political incorporation and active immigrant citizenship through a "structured mobilization" of immigrants. By contrast, critics have argued that state sponsored schemes aimed at transmitting specific political skills and modi operandi to immigrants amount to a form of repressive liberalism due to its potentially disciplinary effects (Joppke, 2007). Similar arguments have been made more recently with regard to state sponsoring of transnational activities, as noted above.

\section{Constraints and opportunities in the transnational organizational landscape}

Immigrant organizations face highly varying transnational social fields in terms of opportunities and constraints. While some are enabled by sending and receiving states, others are impeded by various constraints, e.g., geographical, structural and political constrains. Even notwithstanding distance-shrinking technologies, geographical distance tends to limit transnational activities. Migration therefore typically lead to a reduction of connections to the country of origin as it pulls individuals in sending and receiving countries apart. With time, the social distance between migrants and stay-at-homes tend to increase, which may further reduce the motivation to maintain ties to the sending country, as Waldinger (2013) points out. Nevertheless, actors such as sending and receiving country states shape transnational activities and may contribute to increasing or lowering the costs thereof. Some transnational activities may be promoted by supranational organizations, such as various UN agencies, and international NGOs such as Amnesty, whose issues may overlap with those of immigrant organizations. The possibility of convergence of viewpoints and agendas among immigrants and supranational or receiving-country institutions and organization can be used to muster support for or criticism of origin-country authorities. At the same time, national and supranational forces, such as the internationalized security regime that emerged in the wake of the War on Terror, may also curb transnational activities, as in the case of Muslim immigrant organizations that were deterred from engaging in the countries of origin for fear of incrimination (Chaudhary \& Moss, 2019). 
Sending states may be both conducive to, and constraining of, transnational activities on the part of immigrant organizations. Some sending states have specific agencies dedicated to cultivating relations with diaspora groups so as to generate a continuing sense of belonging to the sending-state, and/or to make migrants and expatriates governable. For instance, governments in sending countries may seek to ensure return migration and thus, brain circulation rather than brain drain. In other cases, they may try to use immigrant organizations as expatriate 'lobbyists' for the promotion of the interests of the sending state (Gamlen, 2006). Examples include the Syrian regime that relied on Syrian American and British professional associations to pursue regime interests overseas, and the Chinese government, that has developed structures to bring Chinese immigrant organizations under its control (Chaudhary \& Moss, 2019). Sending countries may also constrain immigrant organizations through transnational repression, that is, the targeting of diaspora activists and immigrant organizations with threats, smear campaigns or violence. In addition, for fear of possible consequences, the political situation in authoritarian origin societies can lead immigrants to abstain from expressing political opposition. Immigrants who left authoritarian countries for more democratic ones may therefore not necessarily engage in sending country politics, as Chaudhary and Moss (2019) point out. Finally, immigrant organizations may abstain from engaging in sending countries due to their inherent instability and persistently weak governance, rendering formally organized attempts at bringing about change seemingly hopeless. Taken together, immigrant organizations may be shaped by a range of different popular, national and transnational forces that seek to bring them under their control.

\section{The Swedish system of state support to immigrant organizations}

The Swedish way of sponsoring and accommodating immigrant organizations is rooted in the Nordic tradition of societal integration through popular movements (folkrörelser). Nordic popular movements mobilized broad segments of society from the second half of the 1800s and onwards, and gained political influence and legitimacy through mass membership. Eventually, the popular movements became institutionalized and integral parts of the governance structures of the Nordic societies. As Takle (2015) argues, the Nordic popular movement tradition of societal integration, is based on the notion of incorporating individuals (and not just immigrants) into society, not merely as individual citizens but also as members of groups and organizations. The policy of sponsoring immigrant organizations is linked to the wider structure of popular movements, and to its specific democratic and bureaucratic ideals. The democratic aspect of the Nordic popular movement ideal prescribes that the organizations within this organizational field ought to be structured such that they mirror the preferences of their members. There is also a bureaucratic-administrative aspect to the movement idea, in that that the organizations linked to the popular movement sphere are expected to be run on formalized, rule-based and impersonal principles, with a democratically elected leadership and an elected board, in the same manner as other formal civil society organizations. An underlying idea behind this normative ideal, is that participation in civil society organizations provides members with a collective voice and a channel into the political system. In addition to this "voice function, the, popular movement organizations function as schools of democracy and administration (Takle, 2015). 
According to Wijkström (2015) the popular movement organizations also has a "career function", in that they enable social mobility for individual members, while simultaneously constituting talent pools through which future political leaders could be developed and recruited.

When immigrants in Sweden began to organize in the post-war period, they were often linked to fields dominated by the popular movements, where they could be offered long-term support and collaborations with educational associations such as the Workers' Educational Association (Arbetarnas bildningsförbund, ABF) and other organizations linked to the labor movement (Odmalm, 2004, p. 107). Thus, since the 1960s, immigrant organizations in Sweden tended to develop close relationships with the educational associations (studieförbunden), especially with regard to various educational programs and courses (Dahlstedt et al., 2011). The fact that several immigrant groups chose to organize themselves by forming organizations and National Associations based on ethnicity was a rational choice in that it provided access to valuable social and economic capital. By forming and joining National Associations, the immigrant organizations strengthened their legitimacy and gained access to public support and collaborations with authorities and other national associations (Emami, 2017).

However, the question of whether or not ethnic minorities and immigrants ought to be supported for organizing on the basis of ethnicity has been debated in Sweden since the 1960s. According to Dahlström (2004) the Swedish integration policies have oscillated between a Canadian-influenced multicultural perspective, according to which the reproduction of ethnic and cultural traits among immigrants should be supported, and a more assimilationist position. This resulted in somewhat ambivalent policies that seemingly attempted to do both. By the 1980s, a bureaucratically-structured system of National Associations, based on narrowly defined national/ethnic identities such as Finns, Yugoslavs, Greeks, or Kurds, had been established. The National Associations were incorporated into a wider system of interlinked state institutions, organizations, parties (especially the Social Democratic Party), councils and trade unions. Within this system, the Swedish National Board of Immigration (Statens Invandrarverk, SIV) was tasked with monitoring the state-supported immigrant associations. In order to qualify for support, local immigrant organizations had to be subsumed under one central organization, or National Association (riksförbund) so as to facilitate collaboration with SIV. The formation of unified National Associations ensured access to long-term funding. At the same time, it compelled local organizations with different outlooks and political profiles to unite under one banner, which was not always possible. SIV monitored the central organizations by ensuring the state guidelines, compliance with which was required for continuous support, were followed. Moreover, SIV acted as an intermediator between the immigrant associations and a host of other central and local government institutions and civil society organizations (Schierup, 1991). In Schierup's (1991) critical view, this system amounted to a form of political socialization with disciplinary effects, effectively serving to hold back the immigrants' potential for developing organizations that could break out of the established political framework.

Since the 1980s, the corporatist system, as well as the administrative structures surrounding the immigrant organizations, have undergone fundamental changes. The close ties between the state and various interest groups that characterized the corporatist system began to dissolve in the 1990s (Reuter et al., 2017). The responsibility for 
administrating the grants was transferred from SIV to a new government agency, the integration agency (Integrationsverket). As the pendulum swung towards integration, the grants regulating support to ethnic and immigrant organizations came to emphasize integration rather than cultural preservation to a greater extent than before (Borevi, 2004). For instance, the ordinance regulating support for immigrant organizations passed in 2000 stipulated that immigrant organizations had to formulate a plan on how it was to promote integration for the next three years to qualify for support. It is not entirely clear how this affected the activities of the state supported immigrant organizations. Dahlstedt's (2003, p. 68) study of Swedish ethnic national associations showed that they were engaged in both cultural preservation and integration-promoting activities around the turn of the millennium.

The integration agency was closed down in 2007 and the responsibility for administering grants to ethnic organizations was transferred in 2008 to the National Board of Youth Affairs (Ungdomsstyrelsen), which later changed its name to The Swedish Agency for Youth and Civil Society (Myndigheten för ungdoms- och civilsamhällesfrågor, MUCF). The current ordinance 2008:63 regulating state subsidies to organizations formed on the basis of ethnicity (Förordning, 2008:63 om statsbidrag till organisationer bildade på etnisk grund) was introduced that same year. In line with the popular movement ideals, ordinance 2008:63 emphasizes the importance of democratic principles, stating that the associations must have a democratic structure and engage in activities that are not in violation of democratic principles. The ordinance decrees that the grantee organizations should arrange activities that concern culture, language, identity, as well as contribute to increasing participation in society through activities that lead to "increased participation in society for target groups and members" (MUCF, 2018, p. 17). However, the explicit demands for integration had been removed and the current grant regulations are rather ambivalent in that they do not stipulate any specific expectations. MUCF maintains that this specific type of grant differs from other organizational grants in that it does not explicitly "indicate any expected effect on the societal or individual level of the target group's position" (ibid, p. 17). Nevertheless, even though the explicit emphasis on integration had been toned down, the Swedish system of state support to immigrant organizations must be understood in the wider context of the Nordic popular movement system, in which civic associations are meant to contribute to integrating the wider population, not merely immigrants, into the political system, thus providing a sense of ownership in the existing political community and order.

\section{Research methods}

In order to survey the activities of Swedish state-supported ethnic and immigrant organizations, we investigated 52 national associations that received grants from MUCF and that submitted an annual report for the year 2017. A total of 58 organizations were included in grant category in 2017, but of these, five were umbrella organizations for other National Associations, namely the Central Federation of Immigrants, the National Federation of Immigrants, the International Women's Federation, the National Federation of International Women Immigrants (RIFI) and the Cooperative Body for Ethnic Organizations in Sweden (SIOS). These collaborative bodies were not included in the 
study as they do not have local member organizations. In addition, the Iraqi National Federation in Sweden fell out as it did not submit an annual report for 2017.

We divided the associations into four size categories ranging from 1 (very small) to 4 (very large) where 1 comprises 244-1500 members; 2 includes 1501-2500; 3 includes 2501-5000; and 4 comprise 5001-8662 members. We then created a variable based on the time period when the organizations were founded. The first period covers 1945 to 1969. From then onwards, we have periodized into decades up until 1999. The fifth period covers the period 2000-2013, when the last organization included in the study was founded (See type classification in the Additional file 1). We also divided the organizations into four categories based on the members' region of origin; Europe, Middle East and North Africa (MENA), Asia and sub-Saharan Africa (see Table 1 in the Additional file 1).

The main empirical basis of this study consists of the 52 National Associations' annual activity reports, which were analyzed both quantitatively and qualitatively. In these reports, the national associations account for the activities of their member organizations and report them to the MUCF. Initially, we categorized the activities reported in the annual reports and arranged them into 12 activity classes, which we describe below. We then surveyed the existence or not of each activity type within each organization. Based on Ragin (1987), we created a database by coding the activities with a one if it was reported by an organization, or zero if it was not reported.

By constructing a database, we were able to explore relationships among independent variables such as the organizations number of members, the members' region of origin, and the organization's age, size, and number of activity types. In some cases, we have also tested the statistical significance between variables, even though we are aware of the limitations in this regard as the sample is small. Since the organizational population $(N=52)$ is limited, we have mainly used the quantitative results in a descriptive and exploratory sense. Furthermore, we conducted 17 semi-structured in-depth interviews with representatives of the national associations. The sample of respondents was stratified in that we aimed to spread the respondents evenly across different types of organizations on basis of size, age, and region of origin. The selection of informants was also based on availability as some of the representatives declined to participate in the study. In the sections covering the relationship to the country of origin, we have chosen to anonymize some of the organizations, given the politically sensitive nature of the issues considered. It should also be mentioned that there is an inevitable bias in the study's source material in that the annual activity reports may include self-censorship. It is reasonable to assume that the activities accounted for in the activity reports are compatible with the stated aims of the funding authorities.

\section{An overview of the organizational population}

The member organizations of the 52 National Associations included in the study have a total membership of 127,935 individuals distributed over 1046 local associations (see Table 2 in the Additional file 1). Each National Association had an average of near 18 member organizations. The smallest association had only four local member organizations, while the largest had 58 member organizations. Most of the organizations in the study (just over $73 \%$ ) are very small (just over $42 \%$ ) or small (close to $31 \%$ ), while $11.5 \%$ are large and just over $15 \%$ are very large. 
The gender distribution is fairly even, even though the stated number of women is slightly higher (just over $51 \%$ ). In terms of region of origin, just over $46 \%$ of the organizations represented members originating in Europe, just over 23\% had members that originated in the Middle East and North Africa, just over 19\% in sub-Saharan Africa and $11.5 \%$ in Asia. The associations received state-support with median benefits at roughly 300,000 SEK (EUR30000/US30,000) per year, which made up on average 56\% of the associations' total revenues. In the view of resource mobilization theory, the rather substantial reliance on grants on the part of some of the surveyed organizations suggests that they would not have been able to amass the resources required in the absence of state grants. At the same time however, it cannot be precluded that the incentives to create voluntary organizations were altered as a result of the existence of state grants.

All the associations included in the study were founded in the post-war period. Their respective time of establishment probably reflect, at least in part, various migration waves in the post-war period. In the first period 1945-69, four ethnic associations were founded by individuals originating in neighboring countries around the Baltic Sea. Between 1970 and 1980, eight National Associations were founded, mainly for immigrants originating in Southern and Eastern Europe. During the period 1981-1990, seven National Associations were formed with a more geographically varied composition, in terms of sending countries. During the study's fourth period 1991-2000, 16 National Associations were added. One partial explanation for the fact that about twice as many organizations were founded in this period compared to previous periods is that it coincided with the collapse of Yugoslavia, which led to a split of the Yugoslav association. Furthermore, the increasing number of organizations is probably a reflection of a continuous refugee immigration during the 1980s and 1990s. The increasing number of National Associations also seems to be the result of increasing fragmentation within some immigrant groups. Eighteen National Associations with varying origins were founded during the study's fifth and final period 2001-2013. The relatively high number of newcomer associations in the 2000s seems to result partly from a continued fragmentation within some groups, such as the Chinese, Somalis and Bosnians, i.e., nationalities that were already represented by an existing association, at least in the formal sense. In part, the fragmentation trend was rooted in discord between men and women within some of the associations. Women's' sections had in some cases formed their own National Associations in the wake of disunity between male and female board members. In at least one case, the newly formed women's association reclassified itself by applying for grants for women's organization from the Swedish Gender Equality Agency (Jämställdhetsmyndigheten). This suggests that the system of state grants to some extent allowed fragmentation in the sense that an increasing number of National Associations came to represent the immigrants of the same nationality or ethnicity. Clearly, the grant giving authority, MUCF, was not requiring local organizations representing the same nationality to unite under one National Association. Thus, welfare channeling seems to have been one of the factors enabling the fragmentation trend.

Based on the present study, it is not possible to draw any definitive conclusions about causes and motives behind the fragmentation trend. However, the fragmentation itself is quite likely a welfare channeling effect in that some of the newly established organizations would not have existed in the absence of state grants. Thus, the state support seems to have shaped the organizational field of immigrant organizations in this regard. 


\section{An analysis of the organizational activities}

As noted, we distinguished 12 types of activities and explored their prevalence among the 52 studied associations. As seen in Figure 3 (see Figure 3 in the Additional file 1), almost nine out of ten associations reported cultural activities, such as courses trading knowledge about the home country's literature, culture, and musical traditions. More than six out of ten reported political activities and lobbying and more than half of arranged festivities, and various integration, children and sports activities as well as activities aimed at women. The fact that almost all the associations bar a few arranged cultural activities seems to indicate that the immigrant organizations mainly prioritized the preservation of cultural practices, collective memories and identities associated with the country of origin. However, the picture is more complex as the qualitative data indicated that the content of these activities varied greatly. For instance, in one Middle Eastern association a theater group portrayed and interpreted various cultural clashes to help members interpret and cope with life in Sweden. In other cases, the cultural activities served to represent the nationality to others, and spread knowledge of the national culture in question. In other words, the state supported immigrant organizations were engaged in both preserving aspects of culture, and in representing the community, group or nationality, in line with Babis (2016) typological framework.

On average, the associations reported 5.19 activity types. The majority arranged between 3 to 7 different types of activities. At the extreme ends, two organizations reported only one activity type, and two accounted for ten types of activities. While a low number of activity types may seem like a proxy for lack of ambition, it is not necessarily the case, since an organization may be highly committed to only a few activity types. A wider range of activity types can possibly be seen as a proxy for an ambition to achieve institutional completeness though. We cannot tell whether or not such ambitions have contributed to widening the range of activities provided by the organizations in this study. However, the data suggest that the surveyed associations seem to respond to differences in member demand and/or identified member needs. Unsurprisingly, the larger organizations seem to arrange a wider range of activity types. There is a statistically significant $(p=.043)$ relationship between the total number of activity types and the size of the organizations. This explains approximately $15.5 \%$ of the variance of total activities (eta2 $=.155)$. When it comes to the age of the associations, those established between 1981 and 1990 (type 3) showed the widest range of activity types. The oldest (type 1) and youngest (type 5) showed the least breadth of activity, while the unions founded between 1970 and 2000 have a wider range of activities. These differences are partly explained by the fact that a larger proportion of the oldest and youngest organizations were very small. Within type 1 , three out of four organizations were very small, and one small. Within type 5 , more than two thirds (12 of 17 or about $70.5 \%$ ) of the organizations were very small, close to a quarter (23.5\%) were small while only one was very large. The three National Associations for immigrant women, Bosnian-Hercegovina Women's Association (very large), Bosnian-Hercegovina-Swedish Women's Association (small), and the Djibouti Women's National Association (very small), had despite their varying sizes a broader average range of activities, seven on average, than the other organizations. Similarly, associations representing members originating in the MENA-region had a broader range of activity types, also around seven on average, compared with other associations that report an average of four to five activities. The relationship between region of origin and the total 
number of activity types is statistically significant $(p=.011)$ and explains approximately $21 \%$ of the variance (eta $2=.206$ ) in the latter variable. This suggests that the differences in range of activities seem to be partly rooted in different migration histories, and thus, differences in identified member needs for different types of activities. Almost all organizations seem to have recognized a need of cultural activities. Slightly more than half of the associations reported member services aimed at promoting integration, such as assistance with government contacts and support for newly arrived refugees. Integration-promoting activities of this kind were more common in non-European associations. 38\% of European organizations reported integration-oriented activities compared with two-thirds of the MENA and Asian organizations, and 60\% of the African organizations. A likely explanation for this difference is that immigrant organizations with links to refugee sending countries have been particularly active in terms of arranging integration-promoting activities. Our interviews showed that some associations were strongly affected by the refugee wave in 2015. According to representatives of two Middle Eastern associations, the influx of refugees meant that member organizations regularly organized receptions to help refugees book appointments with health care authorities and municipal housing agencies etc. As noted, the immigrant organizations did not have to promote integration as a condition for state support. Nevertheless, many did so, indicating a rather spontaneous civicminded orientation among some of the associations, particularly the Middle Eastern associations, that had identified a need for integration-promoting activities. This finding also suggests that the active integration policies on the part of the government did not crowd out immigrant organizational initiatives, as neo-Tocquevillians might have thought. Even though Swedish government agencies and municipalities offered help and guidance to refugees, ethnic and immigrant organizations offered similar services for their compatriot members. However, while public welfare policies did not crowd out ethnic and immigrant organizations, they seem to have been directed towards certain niches where they offered complementary services with the aim of helping members to navigate the public welfare system. In other words, our data suggests that, despite the fact that immigrants were offered a range public services within the context of the Swedish welfare state, immigrant organizations developed services that complemented those provided by the government organizations. To some extent, this may indicate a shift towards service provision and thus, a shift away from the traditional division of responsibilities among Swedish public, private and civil society organizations, where the latter mainly functions as channels for popular "voice", as noted above.

The trends with regard to labor market-oriented activities and social and public health-oriented work are similar. These are of course also kinds of integration-promoting activities, but we chose to account for them separately to give a clearer picture of the type of integration-promoting activity in question. It should be noted that Swedish state supported immigrant associations are typically not directly involved in providing direct employment services as in Canada, for instance, in line with the pre-existing division of responsibilities among Swedish public, private and civic organizations.

In total, one third of the National Associations reported some form of labor marketrelated support to members, such as training courses on cv-writing and preparatory training for job interviews. Just over two-thirds of the MENA associations reported labor market-oriented activities, compared with almost a third of the African associations, just over a fifth of the European ones and close to a fifth of the Asian. This may 
in part be an effect of different member needs. Representatives of three Eastern European National Associations stated that they did not arrange any integration or labor market-oriented activities, since they perceived of their members as generally well-integrated in the labor market and in society at large.

Social and public health-oriented work, which was most commonly reported among the MENA organizations, where 58\% reported this type of activity, compared with almost a third of the African associations, a quarter of the European associations and close to a fifth of the Asian associations. It is possible that differences in organizational size contributed to this difference between the MENA and the African and Asian associations. While they all engage in promoting integration, the smaller African and Asian association were not able to provide the same range of activities.

Thirty of the fifty-two national associations (close to 58\%) also reported activities aimed at women, such as legal advice on matters concerning family law (e.g., in the Russian and Iranian National Associations), projects concerning domestic violence, and assistance to former housewives to prepare for entering the labor market in Sweden. Five of six Asian (approx. 83\%), 8 of 12 (approx. 67\%) MENA-associations, 13 of 24 (approx. $54 \%)$ European, and 4 of $10(40 \%)$ of African associations reported activities aimed at women. We cannot determine the causes of these differences. It is possible that a higher proportion of female members within the Asian and MENA Associations had come to use the organizations as platforms for pursuing issues that they prioritize. Emphasizing activities directed to women in the annual reports may also be a way to increase the legitimacy of an organization in relation to Swedish authorities and other organizations.

Overall, our data suggests that the surveyed immigrant organizations focused on promoting integration, typically in the form of services aimed at helping members to navigate the welfare system, if they had identified a need for such activities among members. Thus, when perceived as necessary, the surveyed organizations seem to have been driven to assist members to establish themselves in the Swedish society, despite the fact that they were no longer obliged to do so as a condition for state support. This suggests that a share of the state supported associations had developed a spontaneous civic-minded orientation. However, it is possible that public authorities and educational associations may have courted some immigrant organizations more than others by offering collaboration on various integration-promoting initiatives. A share of the integration promoting activities probably stem both from demand for collaboration on the part of the immigrant organizations, and a corresponding supply of collaboration offers on the part of public authorities and educational associations. In other words, governance networks surrounding integration-promoting initiatives involving immigrant organizations, educational associations and public authorities appear to have emerged when a need for such activities had been identified.

\section{Homeland politics, development projects, and opinion-forming activities}

Only eight national associations (just over $15 \%$ ) accounted for development projects and other activities physically located in the country of origin. The share was slightly higher (just over 20\%) within the European associations than within the MENA (close to $17 \%$ ) and the African (one in ten unions) associations. None of the Asian associations reported activities in the country of origin. The projects located in the countries 
of origin were primarily examples of migrant philanthropy, committed to various humanitarian causes. The European National Associations were slightly more active directly in the countries of origin. Geographical proximity probably made it easier for European organizations to operate in the country of origin, while a higher proportion of non-European associations were more constrained geographically, but possibly also politically. For instance, an interviewed representative of a Middle Eastern association considered it too risky to conduct any business in the country of origin, due to the possibility of clashing with local authorities. In this case, the opportunities for transnational activities in located in the country of origin were perceived as blocked.

This is not to say that the state supported immigrant organizations avoided homeland politics and opinion formation activities directed to the countries of origin. $63.5 \%$ of the national associations reported that their members engage in various forms of opinion formation and/or lobbying activities, making it the second most common activity type. This activity category of includes political demonstrations, media and publishing activities, and various forms of lobbying towards politicians.

Opinion formation was most common among the MENA associations (reported by 83\%), and least common among the Asian associations (one third). There was considerable qualitative variation in terms of the types of opinion formation activities that the surveyed organizations engaged in. In part, this seems to have been a reflection of very different conditions within, and towards, the countries of origin. The immigrant associations in Sweden have a history of publishing member magazines, and many still did by the time of this investigation. However, some of the interviewed representatives claimed that demand for printed media aimed at the members in Sweden had decreased due to the rise of internet and social media, enabling direct access for members to media and social spaces in the country of origin. Thus, some of the immigrant organizations seem to have lost an important media function in the wake of the rise of internet. However, the immigrant organizations seem to have been affected in different ways by information technology, partly depending on the political situation in the country of origin and the political orientation of members. While internet seems to have contributed to removing a raison d'être for some organizations, it had become an important tool for others. For instance, one of the National Associations had assumed the role of regime critical platform and worked actively with news coverage and dissemination of regime critical news relating to the country of origin. Since the platform had a global coverage, this case shows that information technology can contribute to a "transnationalization" of the "voice function" traditionally associated with Swedish civil society organizations linked to the popular movements.

On the basis of the interviews and the annual reports, we distinguished six types of approaches towards the country of origin, namely; regime criticism (as noted above), formal cooperation, foreign policy loyalty/domestic policy neutrality, longdistance nationalism, social remittances/institution building and finally stakeholderbased lobbying. It is important to note that these activities could aim at change in Sweden (of Swedish foreign policy, for example) and/or in the country of origin simultaneously. The activities were therefore difficult to locate geographically, insofar as they were directed, if not at a transnational space, then at least at several political and geographical areas at the same time. 
Some of the Swedish National Associations had contacts with diaspora ministries and the like in the countries of origin. At least one cooperated formally with a diaspora council established by the sending state. This National Association disseminated news with the aim of nuancing the notion of the authoritarian sending country regime, as it tended to be portrayed by established Swedish media. The association received minor grants for festive events from the origin state embassy. Thus, in this case the sending state had included the Swedish National Association as a node into a wider transnational governance network, involving diaspora organizations in multiple countries. As such, the sending state played an enabling role, albeit a modest one, in relation to the Swedish National Association.

Other associations had taken a more cautiously loyal attitude towards the state of origin. In order to maintain unity among members who disagreed on domestic politics, both in Sweden and in the country of origin, two associations remained neutral on such issues. At the same time, they were able to unite around a position of foreign political loyalty to the sending country state. The stance is thus one of foreign policy loyalty and domestic policy neutrality. It is possible that this stance is rather typical for associations with politically heterogeneous members who did not migrate primarily as political asylum seekers. Facing domestic policy heterogeneity, immigrant associations may be compelled to assume a neutral position to avoid internal conflict and disintegration.

Another position was that of long-distance nationalism. According to one of the interviewed representatives, establishing a nation-state was an active goal of the National Association and its member organizations. The association actively engaged in opinion formation and lobbying with the long-term goal of establishing a sovereign nation-state in the region of origin. The National Association continuously made statements in the media, sent formal protests to foreign embassies and arranged seminars on issues related to the area of origin. Occasionally, the association coordinated demonstrations with diaspora organizations throughout Europe, meaning that it constituted a node in a transnational network of immigrant organizations. In addition, the National Association had established a "friendship group" in the Swedish parliament that included representatives of all parliamentary parties. Within this group, various issues concerning the area of origin were discussed. As a result of the continuous involvement in the area of origin, several members had generated valuable, bridging social capital in the form of connections to members of the Swedish parliament and representatives of the diaspora in Europe. Even though the members were deeply engaged in homeland politics, they simultaneously contributed to strengthening their social capital in Sweden. This finding indicates that commitment to homeland politics may at times generate bridging social capital that serve an integrative purpose in the receiving country. There is reason to further investigate further whether more general support for the hypothesis that a strong commitment to homeland politics increase career opportunities in the receiving country can be found. The hypothesis put forward here is that immigrant organizations in some circumstances promote what can be called homeland-oriented integration, possibly as a side-effect or unintended consequence. Homeland-integration is thus a hypothetical mechanism for political incorporation resulting from structured mobilization through immigrant organizations.

The tendency of homeland-oriented integration seemed even more pronounced within the Somali National Association in Sweden. The association was part of a co- 
development program (the only one of its kind by the time of the investigation), funded by SIDA, Sweden's government agency for international development cooperation. The program channeled aid funding to Somalia via the independent aid organization Forum Syd (Kleist, 2018). As a result of its cooperation with Forum Syd, representatives of the Somali National Association were included into various governance networks with Swedish government agencies and organizations, such the Ministry of Foreign Affairs and SIDA. Due to its incorporation into a transnational aid network, the connections between the Somali National Association and various Swedish authorities appear to have solidified. One outcome of this collaboration seems to be homeland-oriented integration of participating members. The Somali National Association approach to the country of origin was oriented towards social remittances and institution building, that is, the transfer of "good governance"-standards and institutions to Somalia, since the association had committed itself to the official Swedish aid goals.

The final type of political stance that we discerned among the surveyed National Associations was that of stakeholder-based lobbying. This type of approach can be exemplified by the Finno-Swedish National association, in that it represented a member group with relatively specific and well-defined interests, in this case, the goal of achieving national minority status for Finno-Swedes in Sweden.

These findings indicate that the state support per se did not promote depoliticization, even though it is likely that the Somali organizations had to comply with more stringent conditionalities for continued cooperation in the codevelopment program described above. Some of surveyed associations were explicitly political and engaged in different types of national and homeland-oriented politics. The fact that there was a good deal of variation in terms of political stances indicates that state support neither lead to conformism, nor that it directly influenced the content of the activities. Differences in the transnational fields of the surveyed associations seem to have led to different types of homeland-oriented politics, ranging from open regime criticism to formal cooperation and stakeholder lobbying. The roles of origin country states also differed diametrically. In at least one case, the origin regime assumed an enabling role for the Swedish national association. For others, transnational activities in the country of origin were viewed as impossible, such as for political refugees who would risk imprisonment or deportation. An interviewed representative of a Middle Eastern National Association maintained that the sending state was hostile to the organization and therefore monitored its activities. While this example did not amount to immediate repressive transnationalism, the Swedish Security Service (SÄPO) has registered unlawful intelligence activities that target minority groups and dissidents in Sweden in other cases.

In sum, our findings suggest that the National Associations and their member organizations were embedded in different types of transnational networks and thus, that they occupied different positions of authority as a result of their relations to various other public and private organizations, including foreign state agencies, in line with the analyses of Bloch and Hirsch (2018), Collyer and King (2015) and Koinova (2018). The surveyed organizations thus faced different types of constraints and opportunities in their respective transnational social fields, leading to highly varying political stances and approaches to the areas of origin. 


\section{Conclusions}

This study set out to explore the kinds of activities that immigrant organizations arrange in a welfare state context. The study also investigated how state supported National Associations in Sweden relate to the countries of origin, in terms of both political stances and transnational activities more generally. The study shows that almost all Swedish immigrant organizations that received state support arranged various cultural activities. At the same time, only around $15 \%$ of the surveyed associations reported concrete activities located in the country of origin. The few reported projects located in the sending countries were mainly of a philanthropical kind. At face value, this seems to suggest that that Swedish state supported immigrant organizations were somewhat apolitical, serving mainly the members' needs of preserving selected aspects of the homeland culture. However, a closer look reveals a far more variegated picture. The cultural activities were often arranged in parallel with a number of integrationpromoting activities, and these activities appeared to be both compatible and often overlapping. Among the associations representing members originating in the Middle East, integration-promoting activities were more commonly reported than in European associations. This indicates a rather spontaneous civic-minded orientation among immigrant organizations that had identified a need for integration-promoting activities, since none of the organizations were explicitly compelled to promote integration as a condition for state support. This finding also suggests that the welfare state context and active integration policies on the part of national and local governments did not crowd out immigrant organizational initiatives. Rather, immigrant organizations seem to have been driven to occupy certain niches within the welfare state context where they offered complementary services, often with the aim of helping members to navigate the public welfare system. However, it is likely that the Swedish welfare state with its pre-existing institutionalized relations among government agencies and civil society organizations contributed to shaping the type of integration-promoting activities that the surveyed associations engaged in, for instance by offering collaborations on integration projects and initiatives.

Our findings moreover indicate that state support per se did not promote depoliticization, political compliance or conformism. Some of the surveyed associations were explicitly political in various ways, both vis-à-vis Sweden and the origin country regime. The National Associations engaged in different types of homeland-oriented politics, ranging from open regime criticism to lobbying. For some of the associations, certain aspects of transnationalism were perceived as blocked in the sense that they avoided activities in the country of origin for fear of political repression. The transnational activities of the surveyed associations were both enabled and limited by political, geographical and institutional differences in the different transnational fields to which they were linked. In other words, the National Associations faced different types of constraints and opportunities in their respective transnational organizational landscape, leading to highly different political stances and approaches to the areas of origin. This study suggests that the National Associations and their member organizations had a rather large room for political maneuver. The immigrant organizations were largely free to cooperate with other states, even authoritarian regimes. The freedom to arrange various activities and to join various governance networks, both national and transnational, seems to have been considerable for those that had the capacity to do so. This 
is not to say that the state support, and the vague goals attached to it, did not shape the social landscape of the immigrant organizations, and their activities. Some of the organizations may have interpreted the rather vague regulatory goals in a literal sense, whereas others interpreted them more liberally. Thus, the activities arranged seem to be results of how the associations interpreted their mandate, which varied considerably. It is moreover possible that there were disciplinary, path-dependent effects of preexisting regulatory structures that shaped the practices of older organizations, while newer organizations were less affected by pre-existing regulatory regimes. Moreover, it is likely that public authorities and educational associations may have influenced some immigrant organizations more than others by offering collaboration on courses and other integration-promoting initiatives. In other words, the system of state support may have contributed to the political socialization of members in various ways. However, determining this with any degree of certainty was beyond the scope of our data. On the basis of our data, it seems likely to conclude that the state engendered channeling effects. The fragmentation trend in the 2000s and the low levels of reported activities in some cases indicate state channeling effects in the sense that some associations probably would not have existed in the absence of grants. State support thus shaped the organizational field of immigrant organizations. However, it does not seem to have directly influenced the political content of the activities. Rather it shaped the organizational field in that more organizations, some of them not particularly active, came into existence than would have been the case in the absence of grants. In other words, the existence of many organizations may have been a channeling effect, but the content and direction of their political activities, were not, at least not in an immediate sense.

The study comes down in favor of the thesis that state support can promote immigrant organization and political incorporation, as suggested by Bloemraad (2005, 2006), albeit with a few caveats. In some cases, the state supported organizations seem to have contributed to homeland-oriented integration, that is, the creation of bridging social capital in the receiving country as a result of engagement in homeland politics. We maintain that this is a hypothetical mechanism for political incorporation through immigrant organization, warranting further research. This seemingly promising outcome notwithstanding, the consequences of state support for ethnic and immigrant organizations probably depend on the minutiae of regulation. It should be noted that Swedish regulations were lax by the time of this investigation, and as the devil may be in the regulatory details, the effects of state support found in this study may not be generalizable. This study therefore calls for more research on the regulatory effects of different kinds state support to civil society organizations in general, and immigrant organizations in particular.

\section{Supplementary Information}

The online version contains supplementary material available at https://doi.org/10.1186/s40878-021-00245-1.

Additional file 1: Table 1. Typology based on Region of Origin. Table 2. General Overview of the organizations. Fig. 3. Incidence of Particular Activities. 


\section{Authors' contributions}

The corresponding author was the principal investigator responsible for the framing and compilation of the article. The two co-authors focused on analyzing the quantitative and qualitative material respectively. The author(s) read and approved the final manuscript.

\section{Funding}

The research upon which this study is founded was funded by a grant from the Marianne and Marcus Wallenberg foundation (MMW 2017.0011). Open Access funding provided by Lund University.

\section{Availability of data and materials}

The quantitative dataset is not publicly available but can be shared upon request.

\section{Declaration}

\section{Competing interests}

To the best of our knowledge, there are no conflicts of interest associated with this paper and the funding agent did not influence its result.

Author details

${ }^{1}$ Department of Sociology, Lund University, Box 114, SE-221 00 Lund, Sweden. ${ }^{2}$ Princeton University, Princeton, New Jersey, USA.

Received: 16 March 2021 Accepted: 2 June 2021

Published online: 23 August 2021

\section{References}

Babis, D. (2016). Understanding diversity in the phenomenon of immigrant organizations: A comprehensive framework. International Migration \& Integration, 17, 355-369. https://doi.org/10.1007/s12134-014-0405-x.

Bloch, A., \& Hirsch, S. (2018). Inter-generational transnationalism: The impact of refugee backgrounds on second generation. Comparative Migration Studies, 6(30). https://doi.org/10.1186/s40878-018-0096-0.

Bloemraad, I. (2005). The limits of de Tocqueville: How government facilitates organisational capacity in newcomer communities. Journal of Ethnic and Migration Studies, 31(5), 865-887. https://doi.org/10.1080/13691830500177578.

Bloemraad, I. (2006). Becoming a citizen in the United States and Canada: Structured mobilization and immigrant political incorporation. Social Forces, 85(2), 667-695. https://doi.org/10.1353/sof.2007.0002.

Borevi, K. (2004). Den svenska diskursen om staten, integrationen och föreningslivet. In Justitiedepartementet (Ed.), Föreningsliv, makt och integration Ds 2004:49 Rapport från Integrationspolitiska maktutredningens forskningsprogram (pp. 31-64). Justitiedepartementet.

Breton, R. (1964). Institutional completeness of ethnic communities and the personal relations of immigrants. American Journal of Sociology, 70(2), 193-205. https://doi.org/10.1086/223793.

Cebolla-Boado, H., \& López-Sala, A. (2015). Transnational immigrant organizations in Spain. In A. Portes, \& P. Fernández-Kelly (Eds.), The state and the grassroots: Immigrant transnational organizations in four continents (pp. 160-186). Berghahn Books. https://doi.org/10.2307/j.ctt9qd9c9.15.

Chaudhary, A. R., \& Moss, D. M. (2019). Suppressing transnationalism: Bringing constraints into the study of transnational political action. Comparative Migration Studies, 7(9), 4-22.

Collyer, M., \& King, R. (2015). Producing transnational space: International migration and the extra-territorial reach of state power. Progress in Human Geography, 39(2), 185-204. https://doi.org/10.1177/0309132514521479.

Dahlstedt, I. (2003). Invandrarorganisationer i Sverige. In F. Mikkelsen (Ed.), Indvandrerorganisationer i Norden (pp. 27-94). Nordisk Ministerråd. Akademiet for Migrationsstudier i Danmark.

Dahlstedt, M., Ålund, A., \& Ålund, A. (2011). Villkorat partnerskap: Demokrati och social inkludering i relationer mellan bildnings- förbund och föreningar bildade på etnisk grund. Dansk Sociologi, 21(4), 76-94. https://doi.org/10.22439/dansoc v21i4.3411.

Dahlström, C. (2004). Nästan välkomna. Invandrarpolitikens retorik och praktik. Göteborgs universitet.

DiMaggio, P. J., \& Powell, W. W. (1983). The Iron cage revisited: Institutional isomorphism and collective rationality in organizational fields. American Sociological Review, 48(2), 147-160. https://doi.org/10.2307/2095101.

Emami, A. (2017). Drömmen om ett ett Iranskt paneuropeiskt förbund. In M. Reuter, F. Wijkström, \& A. Emami (Eds.), Civilsamhället i det transnatione llarummet (pp. 101-148). Stockholm: European Civil Society Press.

Faist, T. (2008). Migrants as transnational development agents: An inquiry into the newest round of the migrationdevelopment nexus. Population. Space and Place, 14(1), 21-42. https://doi.org/10.1002/psp.471.

Frödin, O. (2012). Dissecting the state: Towards a relational conceptualization of states and state failure. Journal of International Development, 24(3), 271-286. https://doi.org/10.1002/jid.1743.

Gamlen, A. (2006). Diaspora Engagement Policies: What are they, and what kinds of states use them? (Working Paper No. 32). Retrieved from Oxford

Hein, J. (1997). Ethnic organizations and the welfare state: The impact of social welfare programs on the formation of Indochinese refugee associations. Sociological Forum, 12(2), 279-295. https://doi.org/10.1023/A:1024602000432.

Joppke, C. (2007). Beyond National Models: Civic integration policies for immigrants in Western Europe. West European Politics, 30(1), 1-22. https://doi.org/10.1080/01402380601019613.

Kleist, N. (2018). Somali Diaspora Groups in Sweden. Engagement in Development and Relief Work in the Horn of Africa (Report 2018:1). Retrieved from Stockholm.

Koinova, M. (2018). Critical junctures and transformative events in diaspora mobilisation for Kosovo and Palestinian statehood. Journal of Ethnic and Migration Studies, 44(8), 1289-1308. https://doi.org/10.1080/1369183X.2017.1354158. 
Lacroix, T., \& Dumont, A. (2015). Morrocans in France. In A. Portes, \& P. Fernández-Kelly (Eds.), The state and the grassroots: Immigrant transnational organizations in four continents (pp. 1-24). Berghahn Books.

Morales, L., \& Ramiro, L. (2011). Gaining political capital through social capital: Policy-making, inclusion and network Embeddedness of migrants' associations in Spain. Mobilization, 2(16), 147-164.

MUCF. (2018). Organisationsbidragens användning och eff ekter 2018. Återrapportering av tre statsbidrag till ideella organisationer. Retrieved from Stockholm.

Nijenhuis, G., \& Broekhuis, A. (2010). Institutionalising transnational migrants' activities: The impact of co-development programmes. International Development Planning Review, 32(3-4), 245-265.

Odmalm, P. (2004). Invandrarföreningar som intressekanaler - möjligheter och hinder på lokal nivå. In Justitiedepartementet (Ed.), Föreningsliv, maktoch integration Ds 2004:49 Rapport från Integrationspolitiska maktutredningens forskningsprogram (pp. 99-128). Stockholm: Justitiedepartementet.

Portes, A. (2016). Immigration, transnationalism, and development. The state of the question. In A. Portes, \& P. FernándezKelly (Eds.), The state and the grassroots: Immigrant transnational organizations in four continents (pp. 1-24). Berghahn Books.

Portes, A., Escobar, C., \& Arana, R. (2008). Bridging the gap: Transnational and ethnic organizations in the political incorporation of immigrants in the United States. Ethnic and Racial Studies, 31(6), 1065-1090.

Portes, A., \& Fernández-Kelly, P. (2015). The state and the grassroots. Immigrant transnational organizations in four continents. Berghahn Books.

Pries, L., \& Sezgin, Z. (2012). Cross border migrant organizations in comparative perspective. Palgrave Macmillan. https://doi. org/10.1057/9781137035110

Ragin, CC. (1987). The Comparative Method: Moving Beyond Qualitative and Quantitative Strategies. Berkeley/Los Angeles/ London: University of California Press.

Reuter, M., Wijkström, F., \& Emami, A. (2017). Idéer som reser, containrar som formaterar. In M. Reuter, F. Wijkström, \& A. Emami (Eds.), Civilsamhället i det transnationella rummet (pp. 1-33). European Civil Society Press.

Schierup, C.-U. (1991). The ethnic tower of babel. In A. Ålund, \& C.-U. Schierup (Eds.), Paradoxes of Multiculturalism. Essays on Swedish society (pp. 113-136). Avebury Aldershot.

Takle, M. (2015). Immigrant organisations as schools of bureaucracy. Ethnicities, 15(1), 92-111. https://doi.org/10.1177/14 68796814546575.

Torfing, J. (2012). Governance networks. In D. Levi-Faur (Ed.), The Oxford Handbook of Governance. https://doi.org/10.1093/ oxfordhb/9780199560530.013.0007.

Van Kersbergen, K., \& Van Waarden, F. (2004). 'Governance' as a bridge between disciplines: Cross-disciplinary inspiration regarding shifts in governance and problems of governability, accountability and legitimacy. European Journal of Political Research, 43(2), 143-171. https://doi.org/10.1111/j.1475-6765.2004.00149.x.

Vermeulen, F. (2006). The immigrant organizing process: Turkish organizations in Amsterdam and Berlin and Surinamese organizations in Amsterdam. IMISCOE Dissertations.

Waldinger, R. (2013). Immigrant transnationalism. Current Sociology, 61(5-6), 756-777. https://doi.org/10.1177/00113921134 98692.

Wijkström, F. (2015). Filantroper, frivilliga och sociala entreprenörer. Nya civilsamhällesmedborgare i ett omförhandlat samhällskontrakt. Filip Wijkström. In S. Sörlin, J. M. Stenøien, U. Carlsson, G. Wagner, \& F. Wijkström (Eds.), Medborgarnas Europa - civilsamhällets utmaningar (pp. 61-103). Folkuniversitetet.

\section{Publisher's Note}

Springer Nature remains neutral with regard to jurisdictional claims in published maps and institutional affiliations.

\section{Submit your manuscript to a SpringerOpen ${ }^{\circ}$ journal and benefit from:}

- Convenient online submission

- Rigorous peer review

- Open access: articles freely available online

- High visibility within the field

- Retaining the copyright to your article

Submit your next manuscript at $\boldsymbol{\nabla}$ springeropen.com 